\title{
Leverage Adjustment in Manufacturing Firms: Evidence from Pakistan
}

\author{
Muhammad Mounas Samim, ${ }^{*}$ Shakeel Iqbal Awan, ${ }^{* *}$ \\ Basheer Ahmad $^{* * *}$
}

\begin{abstract}
This study explores firms' leverage behavior and speed of adjustment in the context of selected performance indicators in Pakistan's manufacturing industry. Leverage behavior is predicted using ordinary least squares, based on four performance indicators: profitability, tangibility, size and growth. The speed of adjustment of leverage is estimated using a general linear model and partial adjustment model. We find that profitability, tangibility and growth play a significant role in leverage behavior and the speed of adjustment, although both differ across sectors. Moreover, exponential leverage adjustment appears to be better than linear leverage adjustment.
\end{abstract}

Keywords: liquidation, firm value, leverage.

JEL classification: G310, G320, G330.

\section{Introduction}

This study looks at firms' financial decisions and their short-run and long-run financial operations. There are two types of financing: equity and debt. Most firms use only equity financing, while some use both equity and debt financing in different proportions (Hovakimian, Hovakimian \& Tehranian, 2004). In equity financing, firms pay out dividends, while debt financing incurs interest. Firms that use debt financing along with equity financing are known as leveraged firms. Novy-Marx (2011) argues that firms with higher operating leverage earn higher returns than firms without operating leverage. Capital expenditures and current expenses are met using the cash flow generated by the firm's ongoing operations or projects and by obtaining debt from outside.

\footnotetext{
${ }^{*}$ National University of Modern Languages, Islamabad.

** Iqra University, Islamabad.

**** Iqra University, Islamabad.
} 
Firms use debt to expand their operations; their debt targets are adjusted for accounting periods according to their cash flow. Growth firms use debt conservatively while larger, profitable firms use debt carefully. They will attempt to meet their set leverage targets aggressively (Graham, 2000). Leverage is also the ratio that reflects the ability of the firm to return the loan. There are different ways of calculating firm leverage: Faulkender, Flannery, Hankins and Smith (2012) use the ratio of total debt to total assets plus net income. Debt-availing companies gain a tax shield benefit against interest payments (Graham, 2000). The interest on debt is paid out of the cash inflow, whereas tax is paid on earned income after interest payments.

Firms that avail very large loans compared to equity may risk bankruptcy (Dotan \& Ravid, 1985). Myers (2001) argues that, when availing a loan, the firm's manager should know how much debt is needed against the equity to avoid the cost of bankruptcy under tradeoff theory. Dividends are paid from the firm's retained earnings, which can also be used to invest in core businesses (external opportunities). Dividends are paid after reinvestment in external opportunities, which reflects the firm's residual dividend policy (Smith, 2009).

Of Pakistan's manufacturing firms, about 50 companies are listed on the Karachi Stock Exchange (KSE) 100 index, which reflects the sector's importance in national economic growth. Countries with a relatively developed industrial sector have a higher GDP and better living standards (Easterlin, 2000). In this context, we focus on interest rates and target debt in relation to how firms in Pakistan finance their operations. The process of adjusting the target debt in each accounting period needs appropriate predictions and solutions. Larger firms usually rely on long-term debt, with some proportion of debt adjusted after every accounting period (Barclay \& Smith, 1995). This study looks at the proportion of debt adjustment and identifies hurdles in the speed of adjustment.

\section{Literature Review}

This section discusses the capital structure theories and empirical evidence relevant to leverage adjustment.

\subsection{Market Timing Hypothesis}

The market timing hypothesis shows how investors choose to buy or sell securities according to changes in the market. If the market value of a security is lower than its intrinsic value, this means the security is 
undervalued in the market. In these circumstances, the firm can buy back the security at its real cost: this signals that the real estimate of the security is higher than its market value (Dittmar, 2000). Such market changes, however, tend to be unreliable, and financial analysts need to make better predictions to earn a higher profit. Some investors perform actively in the business sector while others invest in mutual funds instead (Pástor \& Stambaugh, 2002).

Hovakimian (2006) estimates leverage using ordinary least squares (OLS), with the lagged value of profit, tangibility and size as independent variables. Jagannathan and Korajczyk (1986) suggest that artificial market timing can be generated by investing in options such as securities, whereas mutual funds have a negative timing ability. Selectivity and market timing performance are negatively correlated - if the rates of mutual funds are high, then changes in market timing are slow.

Baker and Wurgler (2002) argue that managers assess market timing opportunities based on the ratio of the market value to the book value. Firm valuations are higher when their leverage is low and they are likely to raise their funds. Firm valuations decrease when their leverage increases. Capital structure is affected considerably by variations in market valuation. Becker, Ferson, Myers and Schill (1999) find that investment benchmarks are an important variable as is the information available to investors. If public information is controlled, then benchmark investors are more likely to be highly risk-averse in relation to mutual funds.

Market timing is significant: if stock prices go up, then firms' equity increases (De Bie \& De Haan, 2007). Henriksson (1984) uses parametric and nonparametric tests to determine whether mutual fund managers devise investment strategies based on the return on a market portfolio. According to Elliott, Koëter-Kant and Warr (2008), firms are more interested in issuing an equity if it is overvalued. On the other hand, mispricing is also a significant variable in choosing which securities to issue.

\subsection{Tradeoff Theory}

Under the tradeoff theory, firms decide how much investment will come from equity and how much from debt in order to balance the risk and return. This comparison is made to avoid the risk of bankruptcy associated with using a large amount of debt (Dotan \& Ravid, 1985). Shah and Khan (2007) conclude that there is a tradeoff between tangibility and leverage if a pooled regression analysis is used to estimate leverage. The volatility of depreciation is the opposite of the tradeoff theory. Akinlo (2011) finds that 
growth has a positive relationship with leverage under the tradeoff theory, while tangibility, liquidity and profitability have a negative impact. Hackbarth, Hennessy and Leland (2007) show how the theory explains corporate debt and capital structure. Small firms with the capacity for debt will use only bank debt, while larger firms with a low capacity for debt will resort to the market as well as bank debt proportionally, where the latter accounts for a larger proportion.

\subsection{Pecking Order Theory}

Firms seeking to invest in new external opportunities face a hierarchy of investment options from the most preferable (internal funding) to the least preferable (debt or debt-equity). The more preferable options will have a lower transaction cost. For instance, retained earnings or free cash in hand have no transaction cost. Akinlo (2011) suggests that GDP, sales, liquidity, size and tangibility have a significant and positive relationship with leverage. Shah and Khan (2007) and Akinlo (2011) both conclude that, as the firm's profitability increases, so does its internal financing, thus automatically lowering the use of debt.

Ramlall (2009) measures leverage for a sample of nonfinancial Mauritian firms based on long-term and short-term debt. He finds that tangibility has a positive effect, while liquidity and size have a negative effect on leverage. The no-debt tax shield, profitability and growth have no impact, while the age of the firm affects leverage slightly. Vasiliou, Eriotis and Daskalakis (2009) evaluate the capital structure choices of Greek firms listed on the Athens stock exchange. They argue that a negative relationship between profitability and leverage does not necessarily mean that the pecking order theory applies: sometimes, an increase in profitability may increase the firm's choice to use debt financing.

\subsection{Empirical Literature}

The general phenomenon of repurchase implies that firms tend to buy back securities undervalued by the market. This is done when firms have surplus retained earnings in order to avoid the associated agency cost (Black \& Scholes, 1972) of unspent retained earnings being used by the firm's managers to finance unnecessary projects (Dyl, 1988). Securities are issued when they are overvalued and bought back when undervalued: both actions have the same effect on capital structure decisions (Baker \& Wurgler, 2002). As a result, current capital structure is strongly related to historical market values. 
Firms' cash flow in the short run, the long-run volatility of their capital structure and long operating cycles are forecasted by accruals (timing and matching), which decrease the ability to reflect firm performance (Dechow, 1994). Tangibility and firm size are positively correlated with leverage, but not statistically significant. Leverage is positively correlated with growth and profitability, but the latter is statistically significant whereas growth is not (Shah, Hijazi \& Javed, 2004). If the leverage ratio is high, then the level of risk also rises, which implies that higher leverage is associated with greater variation in stock prices (Bhatti, Majeed, Rehman \& Khan, 2010).

Determinants such as firm size, tangibility, leverage, annual tax, growth and business risk influence the firm's decisions regarding debt and equity (Memon, Bhutto \& Abbas, 2012). Financially constrained business operations are more sensitive to a positive cash flow. In this context, Almeida, Campello and Weisbach (2004) find that unconstrained business operations have weak support in the textiles sector, which implies that it generally has a less than optimal capital structure. Gul, Sajid, Mumtaz and Murtaza (2012) show that asset maturity leads to an increase in long-term debt, while firm size and operating cycles decrease long-term debt. Their pooled model shows a direct, positive relationship between the tax rate and debt maturity. The debt ratio is negatively correlated with profits, the liquidity ratio, variability in earnings and tangibility (asset structure), and positively correlated with firm size (Sheikh \& Wang, 2011).

The capital structure theories discussed above can help explain the financing behavior of Pakistani firms. Gilson (1997) determines the impact of transaction costs on leverage in the presence of different variables. The study uses a basic partial adjustment model to estimate the target leverage and calculates the actual leverage in two different ways. The results show that firms with constrained financing reform their debt, the transaction cost of which raises the debt ratio. According to Axelson, Jenkinson, Strömberg and Weisbach (2009), firms' transaction costs are significantly smaller when their financing is less constrained: their leverage decreases along with the risk of financial distress. Akinlo (2011) uses firm performance indicators to determine capital structure in connection with leverage.

OLS can be used to analyze leverage according to a number of variables. Under the pecking order or agency theory, profitability has a negative impact on leverage, while other independent variables have a positive impact. This shows that, if the firm is earning profits, it is more likely to use retained earnings to meet its financial needs and avoid debt 
(external) financing (Demirgüç-Kunt \& Maksimovic, 1998). According to the tradeoff theory, only growth has a negative impact on leverage. Under agency theory, GDP has a negative impact on leverage.

Shah and Khan (2007) use a sample of industrial firms listed on the KSE-100 index to estimate the optimal capital structure using panel data. The impact of tangibility is in line with the theory, whereas the effect of volatility on depreciation is not. Growth has the expected effect under the agency theory, while firm size does not predict leverage under any theory. Faulkender et al. (2012) find that leverage adjustment is more frequent if transaction costs are lower: if the marginal cost is low, this means that the adjustment will benefit the firm and its capital structure will adjust at the optimal level. Moreover, over-leveraged firms will adjust their leverage targets more rapidly than under-leveraged firms.

The capital cash flow method is easier to use than the free cash flow method. Both are equal if discounted on the cost of capital when deriving leverage adjustment formulae (Ruback, 2002). Kaplan and Ruback (1995) argue that the discounted cash flow method is the most reliable way of assessing the market value of comparable companies. The same variables are significant in relation to firm decisions about debt in developed and developing countries, although Booth, Aivazian, Demirgüç-Kunt and Maksimovic (2001) conclude that understandings of modern financial theory can differ across countries.

\section{Study Aims and Rationale}

We have already established that firms need to finance their shortrun and long-run operational needs - decisions for which their managers are responsible. Generally, firms meet their expenses (operating expenses, interest payments, dividend payments and tax payments) out of their cash inflows. When they cannot do so, they set leverage targets according to their needs and capital structure (debt plus equity). This study evaluates the stream of cash flow patterns and leverage target adjustments.

The general method for computing leverage (total debt / total assets) implies that leverage is low if cash flows - a part of total assets - are high and vice versa. Thus, cash flows affect actual leverage in both directions. We estimate the extent to which leverage is affected by firm performance indicators (the independent variables) and how much leverage is adjusted in each accounting period. The study's specific objectives are to: 
- Examine leverage behavior in Pakistan's manufacturing sector.

- Gauge the strength of the relationship between leverage and factors affecting leverage - growth, size, profitability and tangibility.

- Analyze the functional form of leverage (linear or exponential).

- Determine the speed of adjustment of leverage in the manufacturing industry across different sectors.

- Recommend measures to help financial managers in making decisions about debt adjustment.

Some of the study's assumptions are that (i) indicators such as growth, size, profitability and tangibility affect leverage in manufacturing firms in Pakistan, (ii) linear adjustment is preferable to exponential adjustment, and (iii) leverage adjustment speed is different across sectors within the industry. In this context, we ask the following questions:

- How significant is the effect of profitability, tangibility, size and growth on leverage?

- Does leverage behavior vary across sectors of the manufacturing industry?

- What percentage of actual leverage should be adjusted in each accounting period compared to expected leverage?

- Should leverage adjustments be made linearly or exponentially?

- What should be the speed of adjustment across different sectors?

The study contributes to the literature by taking into account the importance of Pakistan's manufacturing sector to GDP growth. The sector needs to perform efficiently and effectively for firms to meet their goals. Given the poor investment and security climate in Pakistan, firms may find their performance affected, which can result in unreliable sales and cash inflows from other sources. Thus, debt financing is useful when the prevailing interest rates suit the firm's financial conditions. Leverage can help enhance the working capacity of the firm and its working capital strength. Accordingly, our results may be useful to manufacturing firms when making debt adjustment decisions.

\section{Description of Variables}

The dependent variable, leverage, is the percentage of debt. While long-term debt is generally used to calculate leverage, Faulkender et al. 
(2012) use the formula total debt to total assets, given that most firms do not resort to short-term debt. The independent variables include tangibility, size, growth and profitability. These are described below.

The collateral value of a firm's fixed assets significantly affect its ability to obtain debt financing (Rafiq, Iqbal \& Atiq, 2008). Large firms tend to use retained earnings to finance their operations, which means that tangibility and assets are inversely related (Frank \& Goyal, 2009). This variable is calculated using the formula tangibility $=\mathrm{CA} / \mathrm{FA}$ (Elliott et al., 2008). The tangibility of the firm is positively correlated with its leverage, but not statistically significant (Shah et al., 2004).

The size of the firm is measured by sales volume or the log of sales. Size is positively correlated with leverage, but not statistically significant (Shah et al., 2004). Asset maturity leads to an increase in long-term debt while firm size and operating cycles decrease long-term debt (Gul et al., 2012). Size and leverage have a positive relationship when short-term and long-term debt are considered collectively (Sheikh \& Wang, 2011).

While Faulkender et al. (2012) measure firm growth based on the ratio of the market value to the book value of equity, we compute the return on equity (ROE) as net income before tax / shareholders' equity. The effect of growth on leverage differs across the literature. Some studies find that leverage is positively correlated with growth (Shah et al., 2004). Akinlo (2011) shows that growth has a positive relationship with leverage under the tradeoff theory, while Ramlall (2009) argues that growth is not an important factor in variations in leverage. Growth is seen to determine capital structure decisions in Pakistan's textiles sector (Memon et al., 2012).

Profitability is measured in two ways: (i) as earnings before interest and tax and (ii) as the ratio of earnings before tax to total assets (Frank \& Goyal, 2009). We use the formula profitability = net income / total assets. Profitability has a negative impact on leverage under the tradeoff theory, as it increases the firm's internal financing, which lowers the need for debt financing (Akinlo, 2011). The negative effect of profitability on leverage is not always significant because an increase in profitability can also increase the firm's choice to borrow (Vasiliou et al., 2009).

\section{Research Model and Hypotheses}

Figure 1 illustrates our theoretical framework. We use OLS to test the significance of the independent variables. We also evaluate leverage 
behavior and adjustment speed in the manufacturing industry across sectors as well as in the presence of the independent variables, using a partial adjustment model.

Figure 1: Theoretical framework

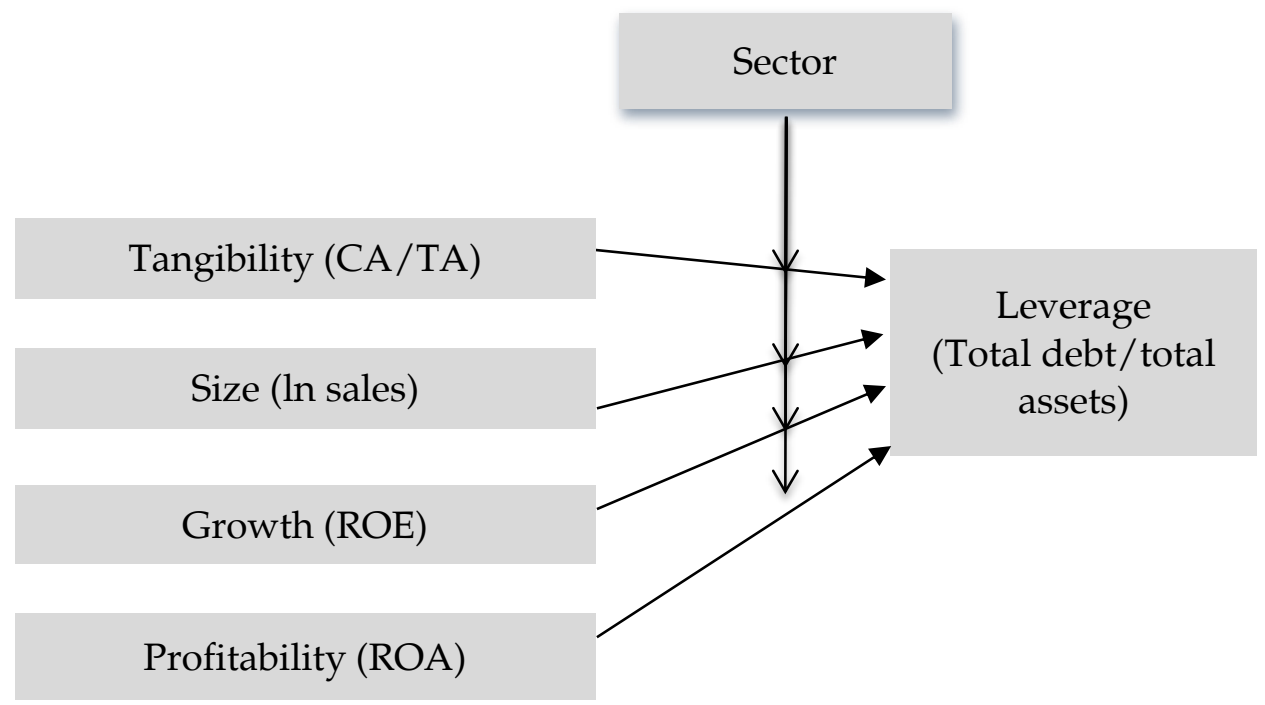

The study's hypotheses are as follows:

- H1: At least one independent variable is a significant predictor of leverage.

- H2: Profitability is a significant predictor of leverage.

- H3: Tangibility is a significant predictor of leverage.

- H4: Growth is a significant predictor of leverage.

- H5: Size is a significant predictor of leverage.

Leverage is estimated across different sectors by controlling for the sector. This implies the following:

- H6: Leverage behavior is different across sectors.

- H7: Leverage adjustment speed is different across sectors. 


\section{Dataset and Methodology}

The study's dataset comprises secondary data on 49 manufacturing firms, across 17 different sectors, listed on the KSE-100 index over the period 2006 to 2013 (see Appendix). The data was taken from the State Bank of Pakistan's annual reports on nonfinancial firms.

Expected leverage is estimated as follows:

$$
Y=\alpha+\beta_{1} X_{1}+\beta_{2} X_{2}+\beta_{3} X_{3}+\beta_{4} X_{4}+\beta_{5} X_{5}+\epsilon
$$

where $Y$ is leverage (the dependent variable), $\alpha$ is the intercept and $\beta_{j}$ denotes the coefficients of the independent variables. $X_{1}$ is the lag of leverage, $X_{2}$ is tangibility, $X_{3}$ is size, $X_{4}$ is growth, $X_{5}$ is profitability and $\in$ is the error term.

The following partial adjustment model is used to evaluate the speed of adjustment of leverage:

$$
L_{t}-L_{t-1}=\gamma\left(L_{t}^{e}-L_{t-1}\right)
$$

where $L^{e}$ is expected leverage (estimated using OLS) at time $t$, and $L_{t-1}$ and $L_{t}$ are the actual leverage at time $t-1$ and $t$, respectively. The left-hand side represents the actual change whereas the right-hand side is the desired change. $\gamma$ is the coefficient of adjustment and lies between 0 and 1. For example, if $\gamma=0.5$, this would mean that 50 percent of the actual leverage was being adjusted in one accounting period. We derive the following regression equations from the partial adjustment model:

$$
\begin{aligned}
& L n L_{t}-\operatorname{Ln} L_{t-1}=\gamma\left(\operatorname{Ln} L_{t}^{e}-\operatorname{Ln} L_{t-1}\right) \\
& L n L_{t}-\operatorname{Ln} L_{t-1}=\gamma L n L_{t}^{e}-\gamma \operatorname{Ln} L_{t-1} \\
& L n L_{t}=\gamma \operatorname{Ln} L_{t}^{e}+L n L_{t-1}-\gamma \operatorname{Ln} L_{t-1} \\
& L n L_{t}=\gamma \operatorname{Ln} L_{t}^{e}+(1-\gamma) \operatorname{Ln} L_{t-1}
\end{aligned}
$$

The sample firms are analyzed one by one in order to differentiate them by functionality, sector and industry. Of the 49 firms initially selected, three were eliminated from the sample due to lack of proper data. Having computed the dependent and independent variables, we apply the regression model to examine the significance of the predictors. Next, we control for the sector as a moderator variable to evaluate the significance of 
all the variables across different sectors. We determine the predicted leverage and use the partial adjustment model to estimate the adjustment speed of leverage, which differs across sectors. Leverage speed is predicted by the coefficient of the speed of adjustment.

\section{Results and Discussion}

This section presents the study's results for the relationship between leverage and the independent variables, the impact of the lagged value of leverage using the partial adjustment model, the effect of the independent variables on leverage across different sectors and the estimated speed of adjustment.

\subsection{Regression Analysis}

Using an autoregressive distributed lag model, the lag of the log of leverage is used as a predictor along with the four independent variables against the log of leverage as the dependent variable. The value of $R^{2}$ (0.761) measures the extent to which these variables explain leverage and gives the model's goodness of fit. The Durbin-Watson $d$ statistic is 2.03, which measures autocorrelation. We apply the Durbin-Watson $h$ test to demonstrate any autocorrelation because we have used the lagged value of the dependent variable:

$$
\begin{aligned}
& \text { Durbin Watson } h=\sqrt{n}\left(1-\frac{1}{2} d\right) \approx N(0,1) \\
& =\sqrt{321}\left(1-\frac{1}{2} 2.073\right)=-0.6205
\end{aligned}
$$

The value of the Durbin-Watson $h$ is -0.6205 , which indicates there is no autocorrelation problem. Profitability, growth and the lag of the log of leverage are found to be significant $\left(\beta=-0.025^{* *}, \beta=0.006^{* *}\right.$ and $\beta=0.758^{* *}$, respectively). The equation comprising the significant variables is:

$$
\text { LnLev }=\beta_{0}+0.758\left(\operatorname{lnLev}_{t-1}\right)-0.025(\text { profit })+0.006(\text { growth })+\epsilon
$$

The coefficient of the log of the lag of leverage (the predictor) is 0.758 , which is equal to the $(1-\gamma)$ term in the partial adjustment model. Thus, $\gamma=1-0.758=0.242$. The positive sign implies that roughly 24 percent of the log of leverage for the manufacturing industry is adjusted in one accounting period, that is, the speed of adjustment of the log of leverage is about 24 percent. Since we have used the log of leverage in this model rather than the original unit, we derive the following: 


$$
L n L_{t}=\beta_{0}+\beta_{1}\left(L n L_{t-1}\right)+\beta_{2}(\text { profit })+\beta_{3}(\text { growth })
$$

This model concerns only the autoregressive predictor of leverage. Adding the value of the coefficient of the log of the lag of leverage, we get:

$$
\begin{aligned}
& L n L_{t}-\operatorname{Ln} L_{t-1}=\gamma\left(\operatorname{Ln} L_{t}^{e}-L n L_{t-1}\right) \\
& L n L_{t}=(1-\gamma) \operatorname{Ln} L_{t-1}+\gamma \operatorname{Ln} L_{t}^{e} \\
& L n L_{t}=(0.758) \operatorname{Ln} L_{t-1}+\gamma \operatorname{Ln} L_{t}^{e} \\
& L n L_{t}=(1-0.242) L n L_{t-1}+\gamma \operatorname{Ln} L_{t}^{e} \\
& L n L_{t}=L n L_{t-1}-(0.242) L n L_{t-1}+\gamma L n L_{t}^{e} \\
& L n L_{t}-L n L_{t-1}=0.242\left(\operatorname{LnL} L_{t}^{e}-L n L_{t-1}\right) \\
& L n L_{t}=0.242\left(L n L_{t-1}\right) \\
& L_{t}=\left(L_{t-1}\right)^{0.242}
\end{aligned}
$$

Equation (16) is used to compute the leverage and its adjustment speed (Table 1).

Table 1: Speed of adjustment of leverage

\begin{tabular}{lcccc}
\hline $\mathbf{L}_{\boldsymbol{t}-\mathbf{1}}$ & $\boldsymbol{L n L}_{\boldsymbol{t}-\mathbf{1}}$ & $\begin{array}{l}\boldsymbol{L n L}_{\boldsymbol{t}} \\
=\mathbf{0 . 2 4 2}\left(\boldsymbol{L n L}_{\boldsymbol{t}-\mathbf{1}}\right)\end{array}$ & $\boldsymbol{L}_{\boldsymbol{t}}=\left(\mathbf{L}_{\boldsymbol{t}-\mathbf{1}}\right)^{\mathbf{0 . 2 4 2}}$ & $\begin{array}{l}\text { Percent } \\
\text { change }\end{array}$ \\
\hline 0.05 & -2.99573 & -0.72497 & 0.4843400 & \\
0.10 & -2.30259 & -0.55723 & 0.5727960 & 0.182631 \\
0.25 & -1.38629 & -0.33548 & 0.7149925 & 0.248249 \\
0.50 & -0.69315 & -0.16774 & 0.8455723 & 0.182631 \\
0.75 & -0.28768 & -0.06962 & 0.9327491 & 0.103098 \\
0.90 & -0.10536 & -0.02550 & 0.9748251 & 0.045109 \\
\hline
\end{tabular}

Source: Authors' calculations.

\subsection{Analysis by Sector}

Having analyzed the leverage variable for the entire sample, we break it down by sector (as the moderator variable) (Table 2). 
Table 2: Results of analysis by sector

\begin{tabular}{|c|c|c|c|c|c|c|c|c|c|c|}
\hline \multirow[b]{2}{*}{ Sector } & \multicolumn{2}{|c|}{ LnLev-1 } & \multicolumn{2}{|c|}{ Tangibility } & \multicolumn{2}{|c|}{ Profitability } & \multicolumn{2}{|c|}{ Growth } & \multicolumn{2}{|c|}{ Size } \\
\hline & B & Sig & B & Sig & B & Sig & B & Sig & B & Sig \\
\hline Chemicals & 0.518 & $0.000^{* *}$ & -3.826 & $0.002^{* *}$ & 0.058 & $0.020^{*}$ & 0.017 & $0.044^{*}$ & 0.017 & 0.887 \\
\hline Cement & 0.591 & $0.000^{* *}$ & -1.888 & $0.004^{* *}$ & 0.041 & $0.002^{* *}$ & 0.008 & 0.171 & -0.005 & 0.934 \\
\hline Foods & 0.391 & 0.209 & -1.550 & 0.553 & -0.0326 & 0.118 & 0.013 & 0.089 & 0.025 & 0.865 \\
\hline Textiles & 0.745 & $0.000^{* *}$ & -0.611 & 0.542 & -0.031 & 0.080 & 0.007 & 0.280 & 0.001 & 0.991 \\
\hline $\begin{array}{l}\text { Ind. metal } \\
\text { and mining }\end{array}$ & 0.322 & 0.424 & -5.353 & -0.0326 & 0.118 & 0.565 & 0.009 & 0.362 & 0.075 & 0.608 \\
\hline $\begin{array}{l}\text { Household } \\
\text { goods }\end{array}$ & 0.040 & 0.949 & 25.837 & $-0.031^{*}$ & 0.080 & 0.748 & 0.012 & 0.570 & 0.749 & 0.474 \\
\hline $\begin{array}{l}\text { Pharma and } \\
\text { biotech }\end{array}$ & 0.181 & 0.620 & -0.001 & $0.004^{* *}$ & 0.565 & 0.832 & 0.000 & 0.723 & 0.001 & 0.785 \\
\hline Tobacco & -0.590 & 0.573 & -12.77 & $0.037^{*}$ & 0.748 & 0.409 & 0.022 & 0.345 & -0.105 & 0.880 \\
\hline Forestry & -0.199 & & 1.881 & & 0.003 & & 0.010 & & 0.453 & \\
\hline $\begin{array}{l}\text { General } \\
\text { industry }\end{array}$ & 0.493 & 0.060 & 0.662 & 0.503 & -0.013 & 0.538 & 0.006 & 0.726 & 0.004 & 0.991 \\
\hline Automobiles & 0.334 & $0.046^{*}$ & -7.834 & $0.003^{* *}$ & -0.201 & $0.017^{*}$ & 0.103 & $0.020^{*}$ & -1.282 & 0.069 \\
\hline $\begin{array}{l}\text { Electronic } \\
\text { and } \\
\text { electrical } \\
\text { goods }\end{array}$ & 0.820 & $0.042^{*}$ & 1.169 & 0.707 & -0.033 & 0.500 & 0.012 & 0.544 & & 0.715 \\
\hline Beverages & 0.338 & 0.470 & -3.077 & 0.233 & -0.099 & 0.321 & 0.032 & 0.629 & & 0.362 \\
\hline
\end{tabular}

Source: Authors' calculations.

The results suggest that leverage behaves differently across sectors. Using a multiple linear regression model, we find that the lag of the log of leverage is significant for five sectors: chemicals $\left(\beta=0.518^{* *}\right)$, cement $(\beta=$ $\left.0.591^{* *}\right)$, textiles $\left(\beta=0.745^{* *}\right)$, automobiles $\left(\beta=0.334^{*}\right)$, and electrical and electronic goods $\left(\beta=0.820^{*}\right)$. Tangibility is significant for six sectors: chemicals $\left(\beta=-3.826^{* *}\right)$, cement $\left(\beta=-1.888^{* *}\right)$, textiles $\left(\beta=0.745^{* *}\right)$, automobiles $\left(\beta=0.334^{*}\right)$ and electrical and electronic goods $\left(\beta=0.820^{*}\right)$. Leverage has a significant relationship solely with tangibility in three other sectors: household goods, pharma and biotechnology, and tobacco. In textiles and in electronic and electrical goods, leverage is affected only by the lag of leverage while the other four independent variables are insignificant.

The coefficient of the lag of the log of leverage (the predictor) is 0.518 , which is equal to the $(1-\gamma)$ term in the partial adjustment model. Thus, $\gamma=1-0.518=0.482$. The positive sign implies that about 48 percent of the log of leverage for the chemicals sector is adjusted in one 
accounting period. Leverage is computed using the equation Lev $=$ $\left(L e v_{t-1}\right)^{\gamma}$ on the basis of the assumed values of leverage (Table 3).

Table 3: Speed of adjustment in chemicals sector

\begin{tabular}{lcccc}
\hline $\mathbf{L}_{\boldsymbol{t} \mathbf{- 1}}$ & $\boldsymbol{L n L}_{\boldsymbol{t - 1}}$ & $\begin{array}{l}\boldsymbol{L n L}_{\boldsymbol{t}} \\
=\mathbf{0 . 4 8 2}\left(\boldsymbol{L n} \boldsymbol{L}_{\boldsymbol{t}-\mathbf{1}}\right)\end{array}$ & $\begin{array}{l}\boldsymbol{L}_{\boldsymbol{t}} \\
=\left(\mathbf{L}_{\boldsymbol{t}-\mathbf{1}}\right)^{\mathbf{0 . 4 8 2}}\end{array}$ & $\begin{array}{l}\text { Percent } \\
\text { change }\end{array}$ \\
\hline 0.05 & -2.99573 & -1.44394 & 0.234585672 & \\
0.10 & -2.30259 & -1.10985 & 0.328095293 & 0.398616083 \\
0.25 & -1.38629 & -0.66819 & 0.511214265 & 0.558127398 \\
0.50 & -0.69315 & -0.33410 & 0.714992493 & 0.398616083 \\
0.75 & -0.28768 & -0.13866 & 0.870020832 & 0.216825128 \\
0.90 & -0.10536 & -0.05078 & 0.950283907 & 0.092254199 \\
\hline
\end{tabular}

Source: Authors' calculations.

The table shows the changes in actual leverage corresponding to the lagged value. If the lag of leverage is 0.05 , then leverage will be 0.234 . If the lag of leverage increases to 0.10 , leverage becomes 0.328 . If the lag of leverage is 0.25 , then the resulting leverage is 0.511. At this level, the adjustment speed is about 56 percent, which is higher than for all other values of leverage. Our overall analysis of this sector shows that the maximum rate of adjustment (55.81 percent) occurs when leverage in the previous period is about 25 percent. Given the same lagged leverage value, the maximum adjustment speed is 45.47 percent in the cement sector, 26.32 percent in textiles, 84.08 percent in the automobile sector and 17.93 percent in electrical and electronic goods. Thus, leverage adjustment in the automobile sector is higher than in other significant sectors.

\subsection{Discussion}

Leverage in the manufacturing industry is affected by profitability, where the negative value of the coefficient reflects the inverse relationship between leverage and profitability. This result is in line with Baker (1973). Profitability enhances the ability of the firm to meet its future financial needs, in turn lowering the need for debt financing and decreasing leverage. Similarly, tangibility has an inverse relationship with leverage, indicating that the firm has a reasonable volume of current assets against total assets and does not need to borrow.

ROE has a positive relationship with leverage, where our results are in line with Titman and Wessels (1988). When demand for the firm's 
product increases, it will expand its current assets to meet the change in demand. The growth in its working capital will increase the size of the firm. In turn, the firm will need more cash to finance the purchase of new assets: if it borrows for this purpose, its leverage will increase. While Titman and Wessels (1988) show that the short-term debt ratio is inversely related to size and positively related to growth, in our overall analysis, size has an insignificant impact on leverage.

\section{Conclusion}

This study examines the changes in leverage associated with four performance indicators - profitability, tangibility, growth and firm size for a sample of manufacturing firms in Pakistan. We find no evidence of a significant relationship between firm size and leverage. There is, however, a significant, inverse relationship between tangibility and leverage, and between profitability and leverage. In both cases, this implies that manufacturing firms earning higher returns (profitability) against their assets will have lower leverage. Consequently, firms need to adjust their leverage targets accordingly.

In addition, leverage varies across sectors, which means that the speed of adjustment is also different. The results indicate that firms with less than 25 percent leverage have a higher rate of adjustment. At levels above 25 percent, the adjustment speed decreases progressively. The sectoral analysis shows that tangibility, profitability and growth have a significant relationship with leverage in all manufacturing sectors. The coefficient of adjustment is significant in only five sectors: chemicals, cement, textiles, automobiles, and electrical and electronic goods. The remaining sectors have insignificant coefficients of adjustment (equal to 0 ), which implies there is no difference between leverage and predicted leverage in these sectors. Thus, no adjustment of leverage is required.

Finally, we argue that the exponential adjustment of leverage is a better predictor than linear adjustment (the log of leverage). The calculated adjustment speeds of leverage differ across sectors -48.2 percent for the chemicals sector, 40.9 percent for cement, 25.5 percent for textiles, 66.6 percent for automobiles and 18 percent for electrical and electronic goods but the adjustment behavior remains the same. 


\section{References}

Akinlo, O. (2011). Determinants of capital structure: Evidence from Nigerian panel data. African Economic and Business Review, 9(1), 1-16.

Almeida, H., Campello, M., \& Weisbach, M. S. (2004). The cash flow sensitivity of cash. Journal of Finance, 59(4), 1777-1804.

Axelson, U., Jenkinson, T., Strömberg, P., \& Weisbach, M. S. (2009, August). Leverage and pricing in buyouts: An empirical analysis. Paper presented at the $36^{\text {th }}$ Annual Meeting of the European Finance Association, Bergen, Norway.

Baker, M., \& Wurgler, J. (2002). Market timing and capital structure. Journal of Finance, 57(1), 1-32.

Baker, S. H. (1973). Risk, leverage and profitability: An industry analysis. Review of Economics and Statistics, 55(4), 503-507.

Barclay, M. J., \& Smith, C. W. (1995). The maturity structure of corporate debt. Journal of Finance, 50(2), 609-631.

Becker, C., Ferson, W., Myers, D. H., \& Schill, M. J. (1999). Conditional market timing with benchmark investors. Journal of Financial Economics, 52(1), 119-148.

Bhatti, A. M., Majeed, K., Rehman, I., \& Khan, W. A. (2010). Effect of leverage on risk and stock returns: Evidence from Pakistani companies. International Research Journal of Finance and Economics, 58(2010), 32-49.

Black, F., \& Scholes, M. (1972). The valuation of option contracts and a test of market efficiency. Journal of Finance, 27(2), 399-417.

Booth, L., Aivazian, V., Demirgüç-Kunt, A., \& Maksimovic, V. (2001). Capital structures in developing countries. Journal of Finance, 56(1), 87-130.

De Bie, T., \& De Haan, L. (2007). Market timing and capital structure: Evidence for Dutch firms. De Economist, 155(2), 183-206. 
Dechow, P. M. (1994). Accounting earnings and cash flows as measures of firm performance: The role of accounting accruals. Journal of Accounting and Economics, 18(1), 3-42.

Demirgüç-Kunt, A., \& Maksimovic, V. (1998). Law, finance and firm growth. Journal of Finance, 53(6), 2107-2137.

Dittmar, A. K. (2000). Why do firms repurchase stock? Journal of Business, 73(3), 331-355.

Dotan, A., \& Ravid, S. A. (1985). On the interaction of real and financial decisions of the firm under uncertainty. Journal of Finance, 40(2), 501-517.

Dyl, E. A. (1988). Corporate control and management compensation: Evidence on the agency problem. Managerial and Decision Economics, 9(1), 21-25.

Easterlin, R. A. (2000). The worldwide standard of living since 1800. Journal of Economic Perspectives, 14(1), 7-26.

Elliott, W. B., Koëter-Kant, J., \& Warr, R. S. (2008). Market timing and the debt-equity choice. Journal of Financial Intermediation, 17(2), 175-197.

Faulkender, M., Flannery, M. J., Hankins, K. W., \& Smith, J. M. (2012). Cash flows and leverage adjustments. Journal of Financial Economics, 103(3), 632-646.

Frank, M. Z., \& Goyal, V. K. (2009). Capital structure decisions: Which factors are reliably important? Financial Management, 38(1), 1-37.

Gilson, S. C. (1997). Transactions costs and capital structure choice: Evidence from financially distressed firms. Journal of Finance, 52(1), 161-196.

Graham, J. R. (2000). How big are the tax benefits of debt? Journal of Finance, 55(5), 1901-1941.

Gul, S., Sajid, M., Mumtaz, R., \& Murtaza, G. (2012). The determinants of corporate debt maturity structure: A case study of Pakistan. African Journal of Business Management, 6(14), 4998-5003. 
Hackbarth, D., Hennessy, C. A., \& Leland, H. E. (2007). Can the tradeoff theory explain debt structure? Review of Financial Studies, 20(5), 1389-1428.

Henriksson, R. D. (1984). Market timing and mutual fund performance: An empirical investigation. Journal of Business, 57(1), 73-96.

Hovakimian, A. (2006). Are observed capital structures determined by equity market timing? Journal of Financial and Quantitative Analysis, 41(1), 221-243.

Hovakimian, A., Hovakimian, G., \& Tehranian, H. (2004). Determinants of target capital structure: The case of dual debt and equity issues. Journal of Financial Economics, 71(3), 517-540.

Jagannathan, R., \& Korajczyk, R. A. (1986). Assessing the market timing performance of managed portfolios. Journal of Business, 59(2), 217235.

Kaplan, S. N., \& Ruback, R. S. (1995). The valuation of cash flow forecasts: An empirical analysis. Journal of Finance, 50(4), 1059-1093.

Memon, F., Bhutto, N. A., \& Abbas, G. (2012). Capital structure and firm performance: A case of textile sector of Pakistan. Asian Journal of Business and Management Sciences, 1(9), 9-15.

Myers, S. C. (2001). Capital structure. Journal of Economic Perspectives, 15(2), 81-102.

Novy-Marx, R. (2011). Operating leverage. Review of Finance, 15(1), 103-134.

Pástor, L., \& Stambaugh, R. F. (2002). Investing in equity mutual funds. Journal of Financial Economics, 63(3), 351-380.

Rafiq, M., Iqbal, A., \& Atiq, M. (2008). The determinants of capital structure of the chemical industry in Pakistan. Lahore Journal of Economics, 13(1), 139-158.

Ramlall, I. (2009). Determinants of capital structure among non-quoted Mauritian firms under specificity of leverage: Looking for a modified pecking order theory. International Research Journal of Finance and Economics, 31, 83-92. 
Rogoff, K. (1985). The optimal degree of commitment to an intermediate monetary target. Quarterly Journal of Economics, 100(4), 1169-1189.

Ruback, R. S. (2002). Capital cash flows: A simple approach to valuing risky cash flows. Financial Management, 31(2), 85-103.

Shah, A., Hijazi, T., \& Javed, A. Y. (2004). The determinants of capital structure of stock exchange-listed nonfinancial firms in Pakistan [with comments]. Pakistan Development Review, 43(4), 605-618.

Shah, A., \& Khan, S. (2007). Determinants of capital structure: Evidence from Pakistani panel data. International Review of Business Research Papers, 3(4), 265-282.

Sheikh, N. A., \& Wang, Z. (2011). Determinants of capital structure: An empirical study of firms in manufacturing industry of Pakistan. Managerial Finance, 37(2), 117-133.

Smith, D. M. (2009). Residual dividend policy. In H. K. Baker (Ed.), Dividends and dividend policy (pp. 115-126). Hoboken, NJ: John Wiley.

Titman, S., \& Wessels, R. (1988). The determinants of capital structure choice. Journal of Finance, 43(1), 1-19.

Vasiliou, D., Eriotis, N., \& Daskalakis, N. (2009). Testing the pecking order theory: The importance of methodology. Qualitative Research in Financial Markets, 1(2), 85-96. 
Appendix

\section{List of sample firms}

\begin{tabular}{|c|c|c|c|}
\hline & Firm & Sector & \\
\hline 1. & Fatima Fertilizer & Chemicals & 1 \\
\hline 2. & Fauji Fertilizer & & \\
\hline 3. & Fauji Fertilizer Bin Qasim & & \\
\hline 4. & Engro Corporation & & \\
\hline 5. & Dawood Hercules Corporation & & \\
\hline 6. & Arif Habib Corporation & & \\
\hline 7. & Agritech & & \\
\hline 8. & ICI Pakistan & & \\
\hline 9. & Fauji Cement Corporation & Construction and materials & 2 \\
\hline & Lafarge Pakistan Cement & (cement) & \\
\hline & Maple Leaf Cement & & \\
\hline & DG Khan Cement & & \\
\hline 13. & Lucky Cement & & \\
\hline & Kohat Cement & & \\
\hline & Attock Cement & & \\
\hline 16. & Cherat Cement & & \\
\hline & Javedan Corporation & & \\
\hline & Engro Foods & Food producers & 3 \\
\hline & JDW Sugar Mills & & \\
\hline & National Foods & & \\
\hline & Nestle Pakistan & & \\
\hline & Rafhan Maize Products & & \\
\hline & Azgard Nine & Personal goods (textiles) & 4 \\
\hline & Nishat Mills & & \\
\hline & Kohinoor Textile Mills & & \\
\hline & Nishat Chunian & & \\
\hline & Colgate Palmolive Pakistan & & \\
\hline & Bata Pakistan & & \\
\hline & International Steels & Industrial metals and mining & 5 \\
\hline & International Industries & & \\
\hline 31. & TRG Pakistan & Support services & 6 \\
\hline & Feroze 1888 Mills & Household goods & 7 \\
\hline & Glaxo Smith Kline Pakistan & Pharma and biotech & 8 \\
\hline & Abbot Laboratories Pakistan & & \\
\hline
\end{tabular}




\begin{tabular}{llll}
\hline \multicolumn{1}{c}{ Firm } & \multicolumn{2}{c}{ Sector } \\
\hline 35. Pakistan Tobacco Company & Tobacco & 9 \\
36. & TPL Tracker & Tech. hardware and equipment & 10 \\
37. Century Paper and Board Mills & Forestry (paper and board) & 11 \\
38. Ghani Glass Mills & General industrials & 12 \\
39. Package & & \\
40. Thal Limited & & \\
41. Siemens Pakistan Engro Company & & 13 \\
42. Atlas Honda & Automobiles & \\
43. Pakistan Suzuki Motor Company & & 14 \\
44. Indus Motor Company & & 16 \\
45. Millat Tractors & Engineering & \\
46. Pakistan Cables & Electronic and electrical goods \\
47. Murree Brewery & Beverages & 17 \\
48. Shezan International & & \\
49. & Grays of Cambridge Pakistan & Leisure goods & \\
\hline
\end{tabular}

